\title{
Hepatic Complications
}

\author{
Tapani Ruutu and Enric Carreras
}

\subsection{Introduction}

The frequency and severity of TPH liver complications have decreased sharply in the last decade, with some complications that have completely disappeared, such as, for example, Candida liver abscesses. The development of more effective strategies to preventing SOS/ VOD and GVHD has had a marked effect on its clinical presentation (see Chaps. 25 and 49). Finally, prophylaxis with antiviral and antifungal drugs has greatly reduced the incidence of the most common liver infections (Hockenbery et al. 2016). The major liver complications after HSCT are:

\section{T. Ruutu}

Clinical Research Institute, Helsinki University

Hospital, Helsinki, Finland

E. Carreras $(\bowtie)$

Spanish Bone Marrow Donor Registry, Josep

Carreras Foundation and Leukemia Research

Institute, Barcelona, Catalunya, Spain

Hospital Clinic Barcelona, Barcelona University, Barcelona, Catalunya, Spain

e-mail: enric.carreras@fcarreras.es

\begin{tabular}{|c|c|}
\hline $\begin{array}{l}\text { Early after HSCT } \\
\text { (<100 days) }\end{array}$ & $\begin{array}{l}\text { Late after HSCT } \\
\text { (months-years) }\end{array}$ \\
\hline $\begin{array}{l}\text { SOS/VOD } \\
\text { Acute GVHD } \\
\text { (see Chap. } 43 \text { ) } \\
\text { Acute hepatitis } \\
\text { Pharmacological toxicity }\end{array}$ & $\begin{array}{l}\text { Chronic GVHD } \\
\text { (see Chap. 44) } \\
\text { Autoimmune hepatitis } \\
\text { Chronic viral hepatitis } \\
\text { (see Chap. 38) } \\
\text { Cirrhosis and hepatocellular } \\
\text { carcinoma } \\
\text { Iron overload } \\
\text { (see Chap. 46) } \\
\text { Other less frequent }\end{array}$ \\
\hline
\end{tabular}

\subsection{Sinusoidal Obstruction Syndrome}

\subsubsection{Definition}

SOS, formerly called veno-occlusive disease of the liver (VOD), is the term used to designate the symptoms and signs that appear early after HSCT because of conditioning regimen-related hepatic toxicity. This syndrome is characterized by jaundice, fluid retention, and tender hepatomegaly appearing in the first 35-40 days after HSCT (Carreras 2015).

\subsubsection{Pathogenesis}

The hepatic metabolism of certain drugs (e.g., CY) by the cytochrome P450 enzymatic system produces several toxic metabolites (e.g., acrolein). These toxic metabolites are converted into stable (nontoxic) metabolites by the glutathione (GSH) 
enzymatic system and then eliminated. When this process occurs in patients with a reduced GSH activity, caused by previous liver disease or by the action of agents such as BU, BCNU, or TBI, which consume GSH, toxic metabolites are not metabolized. Toxic metabolites are predominantly located in area 3 of the hepatic acinus (around the centrilobular veins) because this area is rich in P450 and poor in glutathione. Consequently, damage to hepatocytes and sinusoidal endothelium occurs predominantly in this zone. Many other factors (see risk factors) can also contribute to endothelial injury.

The first events after endothelial injury caused by toxic metabolites are loss of fenestrae in sinusoidal endothelial cells (SEC), formation of gaps within and between SEC, and rounding up or swelling of SEC. Consequently, red blood cells penetrate into the space of Disse and dissect off the sinusoidal lining, which embolize downstream and block the sinusoids, reducing the hepatic venous outflow and producing post-sinusoidal hypertension. The changes observed in coagulation factors in these patients seem to be a consequence of the endothelial injury and probably play a secondary role in SOS pathogenesis, despite contributing to the sinusoidal occlusion (Carreras and Diaz-Ricart 2011).

\subsubsection{Clinical Manifestations of SOS}

\begin{tabular}{l|l}
$\begin{array}{l}\text { Classical } \\
\text { manifestations }\end{array}$ & $\begin{array}{l}\text { Weight gain } / \text { edema/ascites/ } \\
\text { anasarca } \\
\text { Painful hepatomegaly/jaundice } \\
\text { Consumption of (not refractoriness } \\
\text { to) transfused platelets }\end{array}$ \\
Manifestations of \\
MOF & $\begin{array}{l}\text { Pleural effusion/pulmonary } \\
\text { infiltrates } \\
\text { Renal, cardiac, and pulmonary } \\
\text { failure } \\
\text { Neurological symptoms } \\
\text { (encephalopathy, coma) }\end{array}$
\end{tabular}

aPositive fluid balance not explained by excessive hydration

${ }^{\text {b }}$ Difficult to demonstrate by expected thrombocytopenia

\subsubsection{EBMT Diagnostic Criteria for Adults (Mohty et al. 2016)}

\begin{tabular}{l|l}
$\begin{array}{l}\text { Classical SOS } \\
\text { (Baltimore criteria) }^{\mathrm{a}}\end{array}$ & $\begin{array}{l}\text { Late-onset SOS } \\
\text { b }\end{array}$ \\
$\begin{array}{l}\text { In the first } 21 \text { days } \\
\text { after HSCT }\end{array}$ & $\begin{array}{l}\text { Classical SOS beyond day 21, } \\
\text { OR }\end{array}$ \\
$\begin{array}{l}\text { Bilirubin } \geq 2 \mathrm{mg} / \mathrm{dL}^{\mathrm{c}} \\
\text { and } \geq 2 \text { of the }\end{array}$ & $\begin{array}{l}\text { Histologically proven SOS } \\
\text { following }\end{array}$ \\
$\begin{array}{c}\text { OR Painful } \\
\text { hepatomegaly }\end{array}$ & $\begin{array}{l}\geq 2 \text { of the classical criteria } \\
\text { - Weight gain } \\
>5 \%\end{array}$ \\
$\begin{array}{l}\text { hemodynamical evidence of } \\
- \text { Ascites }\end{array}$ & SOS \\
\hline
\end{tabular}

aThese symptoms/signs should not be attributable to other causes

${ }^{b}$ Mainly observed after conditioning including several alkylating agents (e.g., BU, MEL, or TT)

${ }^{\mathrm{c}}$ Observed in almost $100 \%$ of adults but absent in up to $30 \%$ of children

\subsubsection{EBMT Diagnostic Criteria for Children (Corbacioglu et al. 2018)}

\section{No limitation for time of onset of $\mathrm{SOS}^{\mathrm{a}}$ \\ The presence of two or more of the following ${ }^{\mathrm{b}}$ \\ - Unexplained consumptive and transfusion- refractory thrombocytopenia ${ }^{c}$ \\ - Otherwise unexplained weight gain on 3 consecutive days despite the use of diuretics or a weight gain $>5 \%$ above baseline value \\ - Hepatomegaly (best if confirmed by imaging) above baseline value ${ }^{\mathrm{d}}$ \\ - Ascites (ideally confirmed by imaging) above baseline value ${ }^{\mathrm{d}}$ \\ - Rising bilirubin from a baseline value on 3 consecutive days or $\geq 2 \mathrm{mg} / \mathrm{dL}$ within $72 \mathrm{~h}$}

${ }^{a}$ Up to $20 \%$ of children present late SOS

${ }^{b}$ With the exclusion of other potential differential diagnoses

${ }^{c}$ Weight-adjusted platelet substitution/day to maintain institutional transfusion guidelines

${ }^{\mathrm{d}}$ Suggested: imaging (US, CT, or MRI) immediately before HSCT to determine baseline value for both hepatomegaly and ascites 


\subsubsection{Incidence}

Variable depending on the diagnostic criteria used, center experience, type of patients, and year of HSCT

\begin{tabular}{|l|l|l|}
\hline $\begin{array}{l}\text { Author (period analyzed) } \\
\text { (study type) }\end{array}$ & $\begin{array}{l}\text { Auto- } \\
\text { HSCT }\end{array}$ & Allo-HSCT \\
\hline $\begin{array}{l}\text { Coppell et al. 2010 } \\
\text { (1979-2007) (R) }\end{array}$ & $8.7 \%$ & $13 \%$ \\
\hline $\begin{array}{l}\text { Carreras et al. (1998) (P) } \\
\begin{array}{l}\text { Corbacioglu et al. 2012 } \\
\text { (2006-2009) (P) }\end{array}\end{array}$ & $3.1 \%$ & $8.9 \%$ \\
\hline $\begin{array}{l}\text { Carreras et al. 2011 } \\
(1997-2008)(\mathrm{R})^{\mathrm{b}}\end{array}$ & - & $14 \%$ \\
\hline
\end{tabular}

$R$ retrospective study, $P$ prospective study

${ }^{a}$ Only children and young adolescents

${ }^{b}$ Only adults

\subsubsection{Risk Factors for SOS}

\begin{tabular}{|c|c|}
\hline \multicolumn{2}{|c|}{ Patient-related risk factors ${ }^{\mathrm{a}, \mathrm{b}}$} \\
\hline Age & Younger $<$ older \\
\hline Sex & Male $<$ female \\
\hline Karnofsky index & $100-90<$ lower than 90 \\
\hline $\begin{array}{l}\text { Underlying } \\
\text { disease }\end{array}$ & $\begin{array}{l}\text { Nonmalignant }<\text { malignant }<\text { some } \\
\text { specific diseases }^{c}\end{array}$ \\
\hline $\begin{array}{l}\text { Status of the } \\
\text { disease }\end{array}$ & Remission $<$ relapse \\
\hline $\begin{array}{l}\text { AST level before } \\
\text { HSCT }\end{array}$ & Normal $<$ increased \\
\hline $\begin{array}{l}\text { Bilirubin level } \\
\text { before HSCT }\end{array}$ & Normal $<$ increased \\
\hline $\begin{array}{l}\text { Prior liver } \\
\text { radiation }\end{array}$ & No $<$ \\
\hline Liver status & Normal < fibrosis, cirrhosis, tumor \\
\hline Iron overload & Absent $<$ present \\
\hline CMV serology & Negative $<$ positive \\
\hline $\begin{array}{l}\text { Prior treatment } \\
\text { with }\end{array}$ & $\begin{array}{l}\text { Gemtuzumab or inotuzumab } \\
\text { ozogamicin }\end{array}$ \\
\hline Concomitant drugs & Progestogens, azoles \\
\hline Genetic factors & $\begin{array}{l}\text { GSTM1-null genotype, } M T H F R \\
677 C C / 1298 C C \text { haplotype, etc. }\end{array}$ \\
\hline \multicolumn{2}{|c|}{ Transplant-related factors } \\
\hline Type of HCT & Syngeneic/autologous $<$ allogeneic \\
\hline Type of donor & HLA-identical sibling $<$ unrelated \\
\hline
\end{tabular}

Grade of

compatibility

T-cell in the graft

Type of conditioning

Busulfan

TBI

$\begin{array}{ll}\text { Fludarabine } & 36 \mathrm{~h}<\mathrm{CY} \text { to TBI } 12 \mathrm{~h} \\ \text { GvHD prophylaxis } & \text { CNI included }<\text { included } \\ & <\text { CNI }+ \text { sirolimus } \\ \text { HSCT number } & \text { First }<\text { second HSCT }\end{array}$

Bold characters indicate the most relevant factors

${ }^{a}$ Many factors have been associated with an increased risk of SOS, with those in bold letters seem the most relevant ${ }^{\mathrm{b}}$ Remember that the presence of several risk factors in a patient has an additive effect

'Due to unknown causes, some malignant or nonmalignant diseases, osteopetrosis, adrenoleukodystrophy, thalassemia, hemophagocytic lymphohistiocytosis, or neuroblastoma are associated with a higher incidence of SOS

\subsubsection{How to Confirm the Diagnosis?}

SOS is a syndrome and must be diagnosed clinically, but several tools can help us

Transjugular Permits a safe measurement of the hemodynamic hepatic venous pressure gradient study (HVPG), which evaluates the presence of intrahepatic post-sinusoidal hypertension. A HVPG $>10 \mathrm{mmHg}$ is highly specific ( $>90 \%)$ and moderately sensitive $(60 \%)$ for SOS

Transvenous Transvenous biopsies may be obtained liver biopsies during hemodynamic studies, but false-negative results could be obtained due to the patchy nature of SOS. However, biopsies carry a risk of hemorrhagic complications (e.g., into the peritoneum and biliary tract). Consequently, they are only indicated when a crucial differential diagnosis is required (e.g., SOS versus GVHD?) 


$\begin{array}{ll}\text { Imaging } & \begin{array}{l}\text { They may be helpful to confirm } \\ \text { techniques }\end{array} \\ & \begin{array}{l}\text { hepatomegaly and/or ascites (relevant } \\ \text { differential diagnosis. Baseline and } \\ \text { serial US may be useful for early } \\ \text { detection of SOS } \\ \text { The US abnormalities observed in } \\ \text { SOS (hepatomegaly, splenomegaly, } \\ \text { gallbladder wall thickening, ascites) } \\ \text { are not specific. Decrease in velocity } \\ \text { or reversal of the portal venous flow is } \\ \text { considered more specific for SOS but } \\ \text { usually occurs late in the disease } \\ \text { (reviewed in Dignan et al. 2013) }\end{array} \\ \text { Recently some composite markers } \\ \text { have shown a prognostic value at day } \\ \text { O(L-Ficolin, HA, VCAM-1) and at } \\ \text { diagnosis (ST2, ANG2, L-Ficolin, HA, } \\ \text { VCAM-1) (Akil et al. 2015) }\end{array}$

HA hyaluronic acid, VCAM-1 vascular cell adhesion molecule-1, ST2 suppressor of tumorigenicity-2, ANG2 angiopoietin-2

\subsubsection{EBMT Criteria for Severity Grading}

Classically the severity of SOS was stablished, prospectively, based in a mathematical model or, retrospectively, based on its evolution (resolution or not at day +100 ). Later, SOS may be classified as severe with the development of multiorgan failure MOF. Several systems have been proposed for early prognostication of SOS using scales, including the following elaborated by the EBMT (Mohty et al. 2016).

\begin{tabular}{|c|c|c|c|c|}
\hline & Mild & Moderate & Severe & $\begin{array}{l}\text { Very } \\
\text { severe }\end{array}$ \\
\hline $\begin{array}{l}\text { Time since first } \\
\text { symptoms }\end{array}$ & $>7$ days & 5-7 days & $\leq 4$ days & Any time \\
\hline Bilirubin $\mathrm{mg} / \mathrm{dL}$ & $\geq 2$ to $<3$ & $\geq 3$ to $<5$ & $\geq 5$ to $<8$ & $\geq 8$ \\
\hline $\begin{array}{l}\text { Bilirubin } \\
\text { kinetics }\end{array}$ & & & $\begin{array}{l}\text { Doubling } \\
\text { in } 48 \mathrm{~h}\end{array}$ & \\
\hline $\begin{array}{l}\text { Transaminases } \\
(\times N)\end{array}$ & $\leq 2$ & $>2$ to $\leq 5$ & $>5$ to $\leq 8$ & $>8$ \\
\hline Weight gain (\%) & $<5$ & $\geq 5$ to $<10^{\mathrm{a}}$ & $\geq 5$ to $<10^{\mathrm{a}}$ & $\geq 10$ \\
\hline $\begin{array}{l}\text { Renal function } \\
(\times \text { baseline at } \\
\text { HSCT })\end{array}$ & $<1.2$ & $\begin{array}{l}\geq 1.2 \text { to } \\
<1.5\end{array}$ & $\geq 1.5$ to $<2$ & $\begin{array}{l}\geq 2 \text { or } \\
\text { other data } \\
\text { of } \mathrm{MOF}\end{array}$ \\
\hline
\end{tabular}

This severity grading must be applied once SOS/VOD has been diagnosed applying the criteria mentioned in 49.2.4 Patients belong to the category that fulfills $\geq 2$ criteria. If patients fulfill $\geq 2$ criteria in two different categories, they should be classified in the most severe category

In the presence of two or more risk factors for SOS, patients should be in the upper grade

$N$ normal values aeight gain $\geq 5 \%$ and $<10 \%$ is considered as a severe SOS. However, if the patient does not fulfill other criteria for severe SOS, it is therefore considered a moderate SOS

\subsubsection{Prophylaxis (Dignan et al. 2013; Carreras 2015)}

\begin{tabular}{|c|c|}
\hline Non-pharmacolog & \\
\hline $\begin{array}{l}\text { Avoid modifiable ri } \\
\text { (chelation); treat vi } \\
\text { hepatitis; reduce in } \\
\mathrm{CY}+\mathrm{BU} \text { instead o } \\
\text { (if not possible use } \\
\text { prophylaxis; avoid }\end{array}$ & $\begin{array}{l}\text { Treat Iron overload } \\
\text {; delay HSCT if active } \\
\text { nditioning; use } \\
\text { ry to avoid CNI } \\
\text { d CSA) for GVHD } \\
\text { drugs (progestogens) }\end{array}$ \\
\hline Pharmacological & $\begin{array}{l}\text { Drug (degree of } \\
\text { recommendation) }\end{array}$ \\
\hline Not recommended & $\begin{array}{l}\text { Sodium heparin (2B), } \\
\text { low-molecular-weight } \\
\text { heparin ( } 2 \mathrm{~B}) \text {, } \\
\text { antithrombin III (2B), } \\
\text { prostaglandin-1 (1B), } \\
\text { pentoxifylline (1A) }\end{array}$ \\
\hline Suggested & $\begin{array}{l}\text { Ursodeoxycholic acid } \\
(2 \mathrm{C})^{\mathrm{a}} \\
\text { Defibrotide: In } \\
\text { high-risk adult patients } \\
\text { (2B) }\end{array}$ \\
\hline Recommended & $\begin{array}{l}\text { Defibrotide: In } \\
\text { high-risk children }(1 \mathrm{~A}) \\
{[25 \mathrm{mg} / \mathrm{kg} / \mathrm{d}]}\end{array}$ \\
\hline
\end{tabular}

an two randomized trials, UDCA reduce the incidence of SOS but in other two this effect was not observed. However, in all them, patients with UDCA have a lower TRM

\subsubsection{Treatment (Degree of Recommendation) (Dignan et al. 2013; Carreras 2015)}

Methylprednisolone (2C): Used by some authors. Recommended doses not defined (and range from high to low) and results difficult to analyze. Main risk: to delay treatment with defibrotide, the only agent with proved effectiveness.

Defibrotide (1B): Despite the absence of randomized studies, it is the only agent approved by FDA and EMA to treat severe SOS (>80\% mortality). In these patients: $50 \%$ of complete remission and $>50 \%$ SRV at day +100 . Early treatment 
strongly recommended. Dose: $6.25 \mathrm{mg} / \mathrm{kg}$ q6h in $2 \mathrm{~h}$ during $\geq 21$ days, depending on the response.

\subsection{Hepatitis After HSCT}

Despite the reduction in the incidence of liver complications after HSCT, there remain multiple hepatic causes of elevations of serum alanine aminotransferase (ALT). In addition to the acute viral hepatitis, other noninfectious causes must be considered:

\begin{tabular}{|c|c|}
\hline $\begin{array}{l}\text { VZV, CMV, } \\
\text { EBV, HHV-6 }\end{array}$ & Infrequent (see Chap. 38) \\
\hline $\begin{array}{l}\mathrm{HBV}, \mathrm{HCV}, \\
\mathrm{HEV}\end{array}$ & (see Chap. 38) \\
\hline $\begin{array}{l}\text { Drug-induced } \\
\text { hepatitis }\end{array}$ & $\begin{array}{l}\text { Very frequent. Wide range of severity } \\
\text { (see Sect. 49.3.1) }\end{array}$ \\
\hline Hepatic GvHD & $\begin{array}{l}\text { Exceptional. AST/ALT }>2000 \mathrm{U} / \mathrm{L} \\
\text { usually observed in patients without } \\
\text { or with minimal IS (or receiving DLI) } \\
\text { (see Chaps. } 43 \text { and } 44 \text { ) }\end{array}$ \\
\hline $\begin{array}{l}\text { Autoimmune } \\
\text { hepatitis }\end{array}$ & $\begin{array}{l}\text { True autoimmune hepatitis or } \\
\text { GVHD? Often difficult to } \\
\text { differentiate (see Sect. 49.3.2) }\end{array}$ \\
\hline Other causes & $\begin{array}{l}\text { Severe SOS (see Sect. 49.2), hypoxic } \\
\text { liver injury (septic or cardiac shock or } \\
\text { respiratory failure), acute biliary } \\
\text { obstruction }\end{array}$ \\
\hline
\end{tabular}

\subsubsection{Drug Induced Hepatitis}

\begin{tabular}{|l|l|}
\hline $\begin{array}{l}\text { Druga, } \\
\text { Thiazole antifungals }\end{array}$ & Comments \\
\hline Echinocandins & $\begin{array}{l}\text { Cholestatic }^{\mathrm{d}} \text { or } \\
\text { hepatocellular hepatitis } \\
\text { liver failure }\end{array}$ \\
\hline Fluoroquinolones & $\begin{array}{l}\text { Cholestatic hepatitis or } \\
\text { mild-moderate } \\
\text { hepatocellular hepatitis }\end{array}$ \\
\hline Liposomal AmB & $\begin{array}{l}\text { Hepatocellular hepatitis } \\
\text { Mild-moderate elevation } \\
\text { of alkaline phosphatase }\end{array}$ \\
\hline TMP/SMX & $\begin{array}{l}\text { Hepatocellular hepatitis } \\
\text { Cholestasis. Dose- } \\
\text { dependent effect }\end{array}$ \\
\hline RSA, tacrolimus & $\begin{array}{l}\text { Hepatocellular damage, } \\
\text { increased risk of SOS }\end{array}$ \\
\hline Anticonvulsants & $\begin{array}{l}\text { Hepatitis, hepatocellular } \\
\text { or cholestatic }\end{array}$ \\
\hline
\end{tabular}

\begin{tabular}{|c|c|}
\hline Drug $^{a, b}$ & Comments \\
\hline NSAIDs & $\begin{array}{l}\text { Hepatitis, hepatocellular } \\
\text { or cholestatic }\end{array}$ \\
\hline Acetaminophen & $\begin{array}{l}\text { Hepatocellular hepatitis. } \\
\text { Dose-dependent effect }\end{array}$ \\
\hline Antidepressants & $\begin{array}{l}\text { Hepatocellular hepatitis. } \\
\text { Unrelated to drug dosage }\end{array}$ \\
\hline Ranitidine & $\begin{array}{l}\text { Cholestatic hepatitis, } \\
\text { eosinophilic infiltration }\end{array}$ \\
\hline $\begin{array}{l}\text { Amoxicillin-clavulanic } \\
\text { acid }\end{array}$ & $\begin{array}{l}\text { Cholestatic and/or } \\
\text { hepatocellular hepatitis }\end{array}$ \\
\hline $\begin{array}{l}\text { Antihypertensive } \\
\text { drugs + lipid-lowering } \\
\text { agents + oral } \\
\text { hypoglycemics }\end{array}$ & $\begin{array}{l}\text { Drugs usually associated } \\
\text { in patients with metabolic } \\
\text { syndrome (see Chap. } 55 \text { ) }\end{array}$ \\
\hline
\end{tabular}

$A M B$ amphotericin B, TMP/SMX trimethoprimsulfamethoxazole, NSAID nonsteroidal anti-inflammatory drug

${ }^{a}$ Other than cytostatic drugs

bonline resources for the consultation of toxicities and interactions: https://livertox.nlm.nih.gov

cVoriconazole, posaconazole

${ }^{\mathrm{d}}$ Liver damage with predominant elevation of bilirubin and alkaline phosphatase

${ }^{\mathrm{e}}$ Hepatic damage with predominant elevation of transaminases

${ }^{\mathrm{f}}$ Especially if associated to CNI

\subsubsection{Autoimmune Hepatitis (AIH)}

The main problem with this hepatitis is how to differentiate them from a hepatic GVHD, since pathogenesis, clinical manifestations, and biological changes are practically identical (Dalekos et al. 2002).

\begin{tabular}{|c|c|c|}
\hline & $\begin{array}{l}\text { Autoimmune } \\
\text { hepatitis }\end{array}$ & Hepatic GVHD \\
\hline Jaundice & Usually mild & Various degrees \\
\hline $\begin{array}{l}\text { Other } \\
\text { symptoms }\end{array}$ & $\begin{array}{l}\text { Fatigue, malaise, } \\
\text { many times } \\
\text { asymptomatic }\end{array}$ & $\begin{array}{l}\text { Hepatic tenderness, } \\
\text { dark urine, acholic } \\
\text { stools, anorexia, } \\
\text { usually GVHD in } \\
\text { other organs }\end{array}$ \\
\hline Pathology & $\begin{array}{l}\text { Inflammatory } \\
\text { infiltrate in portal } \\
\text { area, often } \\
\text { penetrating lobes }\end{array}$ & $\begin{array}{l}\text { Inflammatory } \\
\text { infiltrate, loss of smal } \\
\text { bile duct, } \\
\text { degeneration of bile } \\
\text { ductular epithelium, } \\
\text { cholestasis }\end{array}$ \\
\hline Cirrhosis & May be present & Rare \\
\hline$>\mathrm{AST}$ & $\begin{array}{l}\text { Moderate to } \\
\text { severe }\end{array}$ & Less striking \\
\hline
\end{tabular}




\begin{tabular}{l|l|l} 
& $\begin{array}{l}\text { Autoimmune } \\
\text { hepatitis }\end{array}$ & $\begin{array}{l}\text { Hepatic GVHD } \\
\text { Usually normal o } \\
\text { decreased }\end{array}$ \\
\hline >GGT & Marked & $\begin{array}{l}\text { Often found (AIH-1) } \\
\text { (ANA, ANCA, etc.) }\end{array}$ \\
\hline Auto-Ab & $\begin{array}{l}\text { Type AIH-2 } \\
\text { (ALKM, ALC-1) }\end{array}$ & Depends on severity \\
\hline $\begin{array}{l}\text { Response } \\
\text { to steroids }\end{array}$ & Excellent &
\end{tabular}

In bold letter main differential data

\subsection{Cirrhosis and Heparocellular Carcinoma}

\begin{tabular}{|c|c|}
\hline Cirrhosis $^{\mathrm{a}}$ & $\begin{array}{l}\text { - In HSCT with HBV: exceptional } \\
\text { - In HSCT with HCV: } 11 \% \text { at } 15 \text { years; } \\
20 \% \text { at } 20 \text { years (Peffault de Latour } \\
\text { et al. 2004) } \\
\text { - In HSCT with HEV: frequency not } \\
\text { known but rapidly progressive cases } \\
\text { have been reported (see Chap. } 38 \text { ) } \\
\text { - Poorly compensated cirrhosis is a } \\
\text { contraindication for HSCT because of the } \\
\text { prohibitive risk of developing SOS after } \\
\text { MAC. Even compensated cirrhosis has a } \\
\text { high likelihood of hepatic decompensation } \\
\text { after NMA (Hogan et al. 2004) }\end{array}$ \\
\hline Car & $\begin{array}{l}\text { In patients with chronic HCV: } 5 \% \text { at } \\
20 \text { years of new cases per year (Peffault de } \\
\text { Latour et al. 2004). These patients should } \\
\text { undergo surveillance with six monthly } \\
\text { liver ultrasound scans according to } \\
\text { international guidelines }\end{array}$ \\
\hline
\end{tabular}

aThese data correspond to the times when new antiviral agents were not available. No updated data are available bThe cumulative incidence of severe liver complications in HSCT infected with the HCV was $11.7 \%$ at 20 years in multicenter cohort (Ljungman et al. 2012)

\subsection{Other Less Frequent Hepatic Complications}

\subsubsection{Nodular Regenerative Hyperplasia}

After HSCT, occasionally observed in patients with a previous SOS/VOD.
Pathogenesis: Probable consequence of changes in liver blood flow with atrophy of zone 3 of the acinus and hypertrophy of zone 1 (without fibrosis).

Clinical Manifestations: Silent evolution (occasionally increase of AP) until the appearance of portal hypertension (ascites, splenomegaly, thrombocytopenia).

Diagnosis: Investigated by imaging (primarily MRI). Liver biopsy can rule out carcinoma and cirrhosis; need for a needle biopsy (not transjugular or fine-needle biopsy).

\subsubsection{Focal Nodular Hyperplasia}

In one series (Sudour et al. 2009) of HSCT survivors undergoing liver MRI, these lesions were observed in $12 \%$.

Pathogenesis: The likely cause is sinusoidal injury caused by myeloablative conditioning regimens.

Clinical Manifestations: Asymptomatic.

Diagnosis: By MRI, lesions have characteristic central scars that differentiate them from hepatocellular carcinoma and fungal lesions.

\subsubsection{Idiopathic Hyperammonemia}

Very rare. Observed after conditioning (Frere et al. 2000)

Diagnosis: Severe hyperammonemia (>200 $\mu \mathrm{mol} / \mathrm{L}$ ) with minimal alteration of other LFTs.

Clinical Manifestations: Lethargy, motor dyscoordination, and alkalosis. 


\section{References}

Akil A, Zhang Q, Mumaw CL, et al. Biomarkers for diagnosis and prognosis of sinusoidal obstruction syndrome after hematopoietic cell transplantation. Biol Blood Marrow Transplant. 2015;21:1739-45.

Carreras E, Diaz-Ricart M. The role of the endothelium in the short-term complications of hematopoietic SCT. Bone Marrow Transplant. 2011;46: 1495-502.

Carreras E, Bertz H, Arcese W. Incidence and outcome of hepatic veno-occlusive disease after blood or marrow transplantation: a prospective cohort study of the European Group for Blood and Marrow Transplantation. European Group for Blood and Marrow Transplantation Chronic Leukemia Working Party. Blood. 1998;92:3599-604.

Carreras E, Diaz-Beya M, Rosinol L, et al. The incidence of veno-occlusive disease following allogeneic hematopoietic stem cell transplantation has diminished and the outcome improved over the last decade. Biol Blood Marrow Transplant. 2011;17:1713-20.

Carreras E. How I treat sinusoidal obstruction syndrome after hematopoietic cell transplantation. $\mathrm{Br} \mathrm{J}$ Haematol. 2015;168:481-91.

Coppell JA, Richardson PG, Soiffer R, et al. Hepatic veno-occlusive disease following stem cell transplantation: incidence, clinical course, and outcome. Biol Blood Marrow Transplant. 2010;16:157-68.

Corbacioglu S, Cesaro S, Faraci M, et al. Defibrotide for prophylaxis of hepatic veno-occlusive disease in paediatric haemopoietic stem-cell transplantation: an open-label, phase 3, randomized controlled trial. Lancet. 2012;379:1301-9.

Corbacioglu S, Carreras E, Ansari M, et al. Diagnosis and severity criteria for sinusoidal obstruction syndrome/venoocclusive disease in pediatric patients: a new classification from the European society for blood and marrow transplantation. Bone Marrow Transplant. 2018;53:138-45.
Dalekos GN, Zachou $\mathrm{K}$, Liaskos C, Gatselis N. Autoantibodies and defined target autoantigens in autoimmune hepatitis: an overview. Eur J Intern Med. 2002;13:293-303.

Dignan FL, Wynn RF, Hadzic N, et al. BCSH/BSBMT guideline: diagnosis and management of venoocclusive disease (sinusoidal obstruction syndrome) following haematopoietic stem cell transplantation. $\mathrm{Br}$ J Haematol. 2013;163:444-57.

Frere P, Canivet JL, Gennigens C, et al. Hyperammonemia after high-dose chemotherapy and stem cell transplantation. Bone Marrow Transplant. 2000;26:343-5.

Hockenbery DM, Strasser SI, McDonald GB. Gastrointestinal and hepatic complications. In: Forman SJ, Negrin RS, Antin JH, Appelbaum FR, editors. Thomas' hematopoietic cell transplantation. 5th ed. Hoboken: Wiley; 2016. p. 1140-56.

Hogan WJ, Maris M, Storer B, et al. Hepatic injury after nonmyeloablative conditioning followed by allogeneic hematopoietic cell transplantation: a study of 193 patients. Blood. 2004;103:78-84.

Ljungman P, Locasciulli A, de Soria VG, Infectious Diseases Working Party of the European Group for Blood and Marrow Transplantation, et al. Longterm follow-up of $\mathrm{HCV}$-infected hematopoietic SCT patients and effects of antiviral therapy. Bone Marrow Transplant. 2012;47:1217-21.

Mohty M, Malard F, Abecassis M, et al. Revised diagnosis and severity criteria for sinusoidal obstruction syndrome/veno-occlusive disease in adult patients: a new classification from the European Society for Blood and Marrow Transplantation. Bone Marrow Transplant. 2016;51:906-12.

Peffault de Latour R, Lévy V, Asselah T, et al. Long-term outcome of hepatitis $\mathrm{C}$ infection after bone marrow transplantation. Blood. 2004; 103:1618-24.

Sudour H, Mainard L, Baumann C, et al. Focal nodular hyperplasia of the liver following hematopoietic SCT. Bone Marrow Transplant. 2009;43:127-32.

Open Access This chapter is licensed under the terms of the Creative Commons Attribution 4.0 International License (http://creativecommons.org/licenses/by/4.0/), which permits use, sharing, adaptation, distribution and reproduction in any medium or format, as long as you give appropriate credit to the original author(s) and the source, provide a link to the Creative Commons license and indicate if changes were made.

The images or other third party material in this chapter are included in the chapter's Creative Commons license, unless indicated otherwise in a credit line to the material. If material is not included in the chapter's Creative Commons license and your intended use is not permitted by statutory regulation or exceeds the permitted use, you will need to obtain permission directly from the copyright holder.

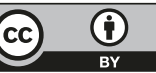

